\title{
THE VARIATION OF SEVERAL WATER QUALITY INDICATORS IN RED LAKE
}

\author{
Melinda VIGH ${ }^{1}$
}

\begin{abstract}
The variation of several water quality indicators in Red Lake. The natural dam lake from the Hăşmaş Massif is supplied by four permanent streams and various torrential courses. Lake water quality parameters are influenced by natural factors of the region, and the touristic activity of the Red Lake Resort. Evaluation of the water body was done on water samples taken in four sampling campaigns/year. Samples were taken from the middle of the lake, at the water surface. The analysis covers two periods separated by an interval of 11 years: 1993-1999 and 2010-2015. Along with the temporal indicators evolution was analyzed also the standard deviation variation. Deficiencies in respect of employment in quality standards were observed at total phosphorus, total nitrogen, and dissolved oxygen. Regarding total phosphorus, which expresses the degree of eutrophication, the lake water was mesotrophic in the first period, and in the second became oligotrophic. In the future this lacustrine ecosystem requires greater protection to prevent more drastic degradation of water quality.
\end{abstract}

Key words. Water body, group of indicators, ecological status, quality class, eutrophication, standard deviation.

\section{INTRODUCTION}

Red Lake is located in the central group of the Eastern Carpathians, in the Hăşmaş Massif, in ecoregion 10. It spans on the eastern side of the mountains Hăşmaşul Mare and Hăşmaşul Mic. It is the biggest natural dam lake in Romania. The lake looks like a drowned valley and the water level is pierced by the trees trunks of an ancient wood. They were preserved until now, due to the presence of calcium carbonate and iron oxide.

The region's substrate consists of conglomerates, limestone and clays. Sometimes appear red sandstones from tertiary period, predominantly oxides and hydroxides of iron.

Lake area is situated within the eastern extremity of the continental oceanic temperate climate. For this region it is typical of the topoclimate of mountain forests and pastures. Thus, the winters are long and cold and summers short and warm, with frequent temperature inversions. The average monthly temperature is between $-5^{\circ} \mathrm{C}$ in January and $14^{\circ} \mathrm{C}$ in July. Extreme values exceed $-25^{\circ} \mathrm{C}$, respectively $30^{\circ} \mathrm{C}$. The number of days with negative temperatures is greater than 160.

${ }^{1}$ Babes-Bolyai University, Faculty of Environmental Science and Engineering, Cluj-Napoca, Romania

E-mail:vmelindap@yahoo.com 
The high mountains around the lake favors the convection of moist air masses and cloud formation that bring precipitation. The average annual quantity is $800 \mathrm{~mm}$ and is distributed in over 200 days of the year. The lake's rain gauge recorded an average value of $773.6 \mathrm{~mm}$ for a period of 22 years. The large amount of snow accumulated during the long winters increase the water level in the lake due to spring melting.

The Red Lake is located in the upper part of the Bicaz River basin, which is a tributary of Bistriţa River. Lake's supply is made from 4 streams with large discharges and a further 12 rivers with temporary discharge regime. The streams with permanent drainage are: in the south the Oii Stream $(18.3 \mathrm{~km})$, southwest Red River (14.5 km), in west Licaș River (3.5 km) and Suhard River (3.2 km). These waters gather together over the natural water dam form Bicaz River.

The shape of the lake resembles the letter $\mathrm{L}$ with two perpendicular arms. The short arm has a length of $440 \mathrm{~m}$ along the Suhard Valley, and the long arm is of $900 \mathrm{~m}$ of the Oii Valley. The lake has an area of $116500 \mathrm{~m}^{2}$, a volume of 606 $500 \mathrm{~m}^{3}$, a depth average of $5.1 \mathrm{~m}$, and an average water retention time of three days (Pandi, 2004). Because of the silt brought by rivers and from the slopes, the lake has a rapid silting pace. So 100 years ago the arms' length was $650 \mathrm{~m}$ and $1300 \mathrm{~m}$. To prevent this phenomenon, on Oii Stream and Red Stream were built two artificial pools that are designed to retain silt, thus slowing down the silting pace.

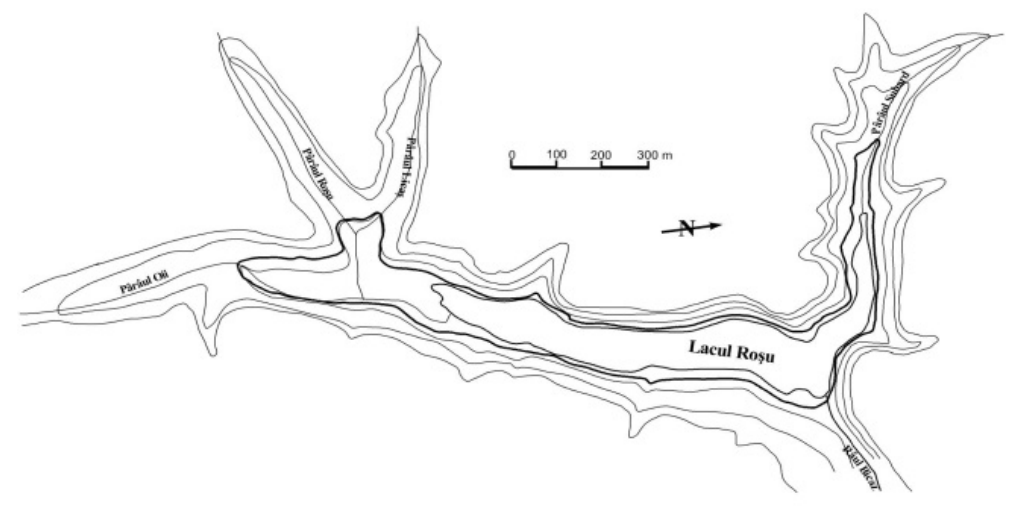

Fig. 1. Red Lake

The dominant basin vegetation is coniferous forests, characteristic to mountains area.

Anthropogenic influence has an increasing impact on lake water quality. Tourism in hostels, restaurants, holiday houses built close to the lakeshore and with non-ecological operation, lead to degradation of lake's water quality.

\section{DATA AND METHODS}

Water samples were collected in sampling campaigns, with random distribution in the months when the surface of the lake was frozen. Every year were collected four samples. There are three monitoring points: the lake entrance, the 
middle of lake and lake's exit. Each campaign was done a biological and a chemical assessment in the water quality of the studied water body.

In this paper they were processed water samples taken from the middle of the lake, at water surface. A comparison was made for the evolution of quality indicators divided into two periods: 1996-1999 and 2010-2015. The study covers some parameters from three groups of indicators:

-acidification conditions: $\mathrm{pH}$,

-oxygen regime: dissolved oxygen, $\mathrm{CBO}^{5}$,

-nutrients: total nitrogen, ammonia, orthophosphate, total phosphorus.

Water samples were analyzed in specialized laboratory in accordance with legislation and the standards of the European Union (OM 161/MMGA). Evaluation was made based on annual average values.

It was also calculated the standard deviation of the quality parameters for the second period of the study. This statistical measure shows the degree of dispersion studied elements around the mean values. It is the most known and used method for expressing the variability of the data. The sum of squares was partitioned to $\mathrm{n}-1$, since the data stream is short. Such calculation formula is:

- where: s- standard deviation

$$
s=\sqrt{\frac{\sum(X-M)^{2}}{n-1}}
$$

$\mathrm{X}$ - parameters' value

M- annual average

n- number of values

\section{RESULTS}

\subsection{The interpretation of quality indicators}

The water quality of a lake is given primarily by biological processes taking place in water, in association with the physical and chemical processes that influence it (Romanescu et al., 2013). The survey about Red Lake water quality is based on an integrated assessment of the 3 groups of indicators. Of each group were analyzed one or more indicators, depending on the representativeness and impact on the water body.

\section{Acidification conditions}

Hydrogen ions' concentration expresses the acidic or basic character of the water body. Red Lake has an alkaline (basic) water because in the entire study period, the $\mathrm{pH}$ values was around 8 . From the point of view of the living things, the water is less harmful (up to 8.2), that is only some plant and animals species live in it.

In the first period there was a continuous decrease in $\mathrm{pH}$ value from 8.1 to 7.7. In the second period values were relatively constant with the exception of 2014, when the $\mathrm{pH}$ value jumped to 8.7, a value that represents a weak alkaline water. 


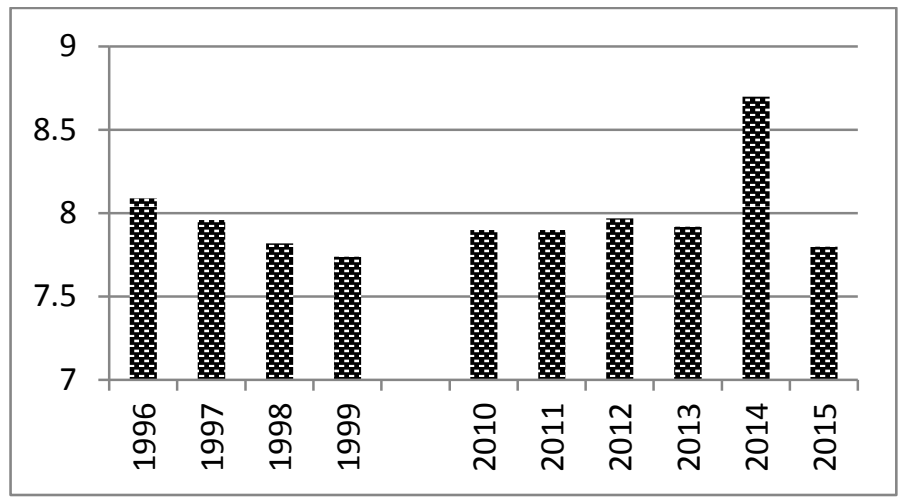

Fig. 2. pH variation

\section{Oxygen regime}

The level of oxygen is very important for the quality of the water body as it determines the water's self-purification capacity (Vigh, 2003).

Dissolved oxygen in the water of the Red Lake is relatively stable. In the first period fluctuations were somewhat higher than in the second. The minimum of $8 \mathrm{mg} / \mathrm{l}$ in 1999 includes the water body only in the II $^{\text {nd }}$ quality class. The second period is more stable and homogeneous $(9.5-10.6 \mathrm{mg} / \mathrm{l})$. This includes the lake water in the $\mathrm{I}^{\text {st }}$ quality class. Good oxygenation on the lake is due to the permanent water transit made by streams and tributaries over the natural dam. The short retention time facilitates a balanced development of aquatic organisms, and a normal oxidation process.

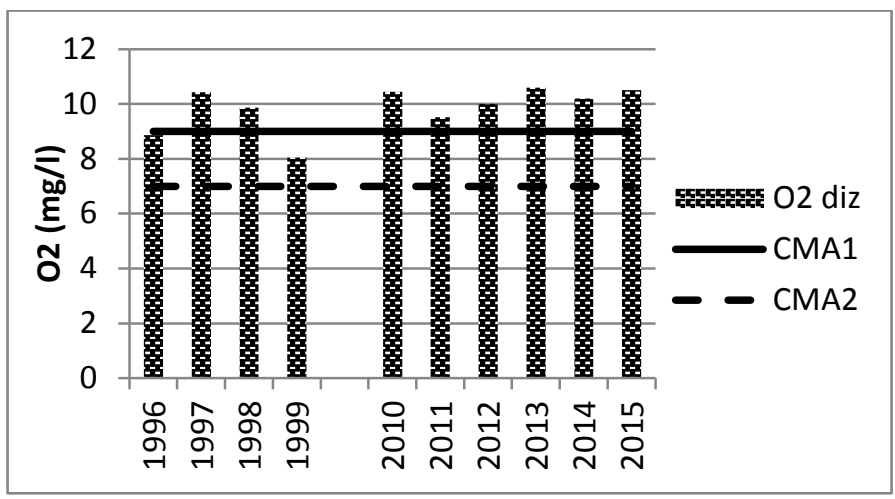

Fig. 3. Dissolved oxygen variation

CBO5 has evolved fairly constant, with values between 2.4-3.0 mg/l. The lake water was included in the $I^{\text {st }}$ quality class throughout the study period. In both periods can be observed a slight tendency of increase of CBO5 values (2.6-3.0 mg/l). It is worth noting that in the second period from 2013, CBO5 values present a big increase. Oxidants start growing aiming at a qualitative decay of the water body. It also increases the ability of biochemical decomposition of organic substances. 


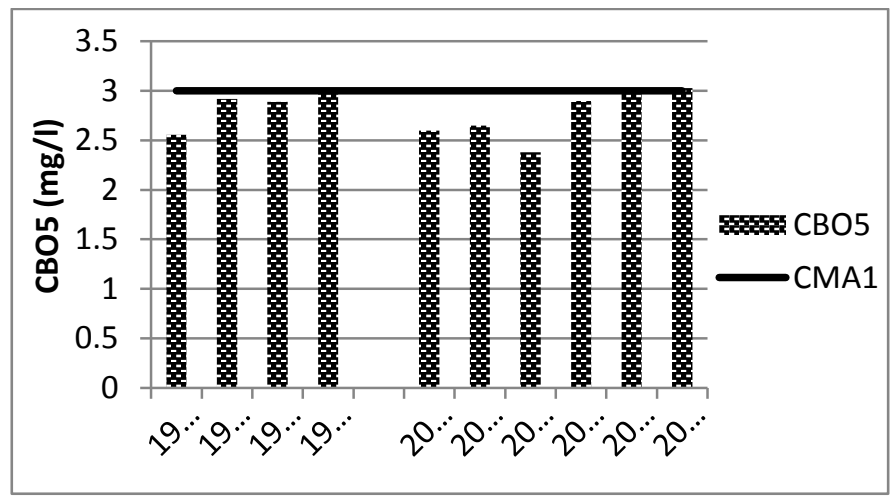

Fig. 4. CBO5 variation

\section{Nutrients}

The most representative are phosphorus and nitrogen, along with combinations thereof. They have relevance both in terms of quality and the degree of eutrophication.

Ammonium comes from advanced decomposition of organic substances. The first period is distinguished by very high value in 1996 (0.3 mg/l) and in 1999 (0.6 $\mathrm{mg} / \mathrm{l})$. In 1997 and 1998 the values were so small that they could not be quantified. In 1999 it exceeded the limit of $0.4 \mathrm{mg} / \mathrm{l}$ for I $\mathrm{I}^{\text {st }}$ quality class. In the second period values are significantly lower, which indicates much slower decomposition processes or a decrease in biomass, as a result of environmental protection measures.

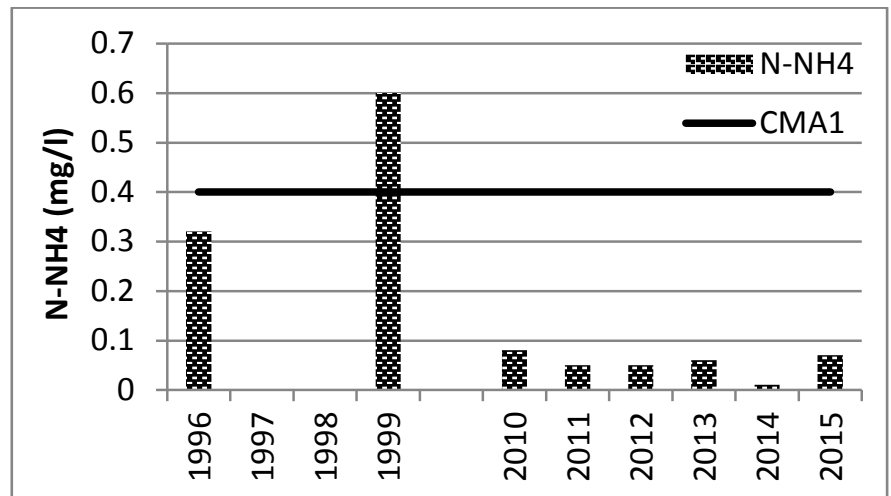

Fig. 5. Ammonium variation

Total nitrogen appeared in small quantities in the studied water body. The highest value is $1.12 \mathrm{mg} / \mathrm{l}$ in 1999, which is well below the permissible limit (1.5 $\mathrm{mg} / \mathrm{l})$. In the first period, the values were somewhat higher, but presented no danger. In the second period nitrogen values were consistently in a proper ratio. In the first period the total nitrogen was increasing, and in the second one was decreasing, except for 2015, when the increase showed an ease on the production of organic matter. This is caused by touristic activity influence. 


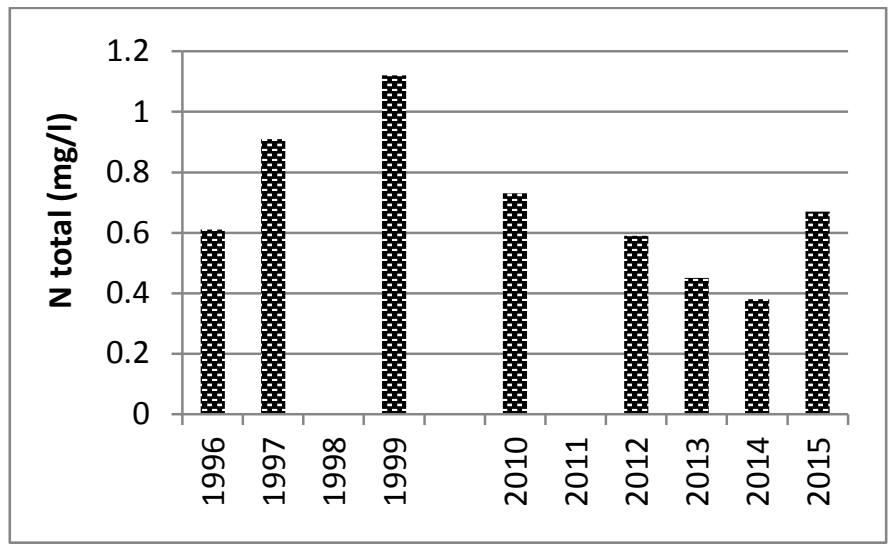

Fig. 6. Total nitrogen variation

Phosphate moiety shows a similar trend with total nitrogen. In the first period the trend was increasing. In the second period there has been a sharp rate decline in values. From 2011 to 2015 the concentration is reduced by $85 \%$. In terms of maximum allowable concentrations $\left(\mathrm{CMA} 1=0.1\right.$ ) both periods fall in the $\mathrm{I}^{\text {st }}$ class. The decrease form the last period is due to improve the aquatic environment.

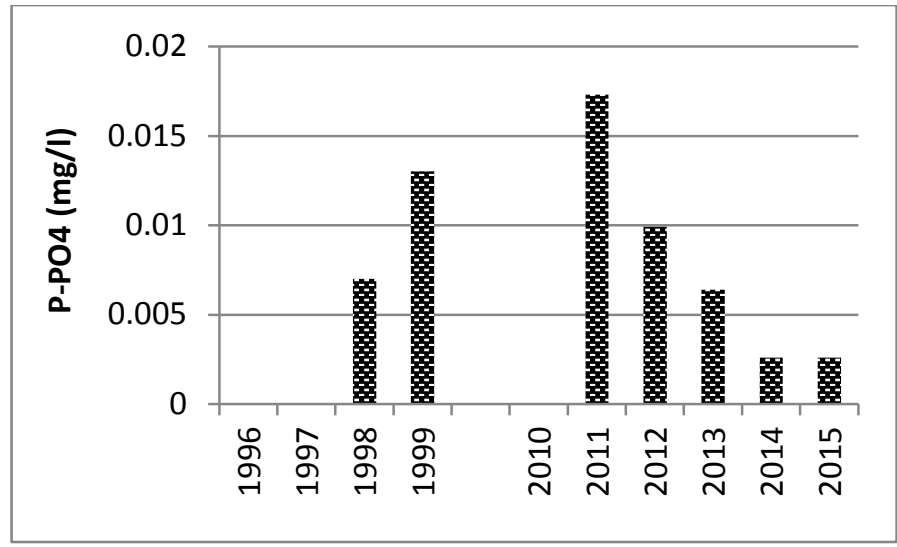

Fig. 7. Phosphate variation

Total phosphorus mostly influences the lake's degree of eutrophication. In the first period the values were higher than in the second. In the first two years of analysis phosphorus had the highest values with a maximum of $0.048 \mathrm{mg} / \mathrm{l}$. This value falls into the III $^{\text {rd }}$ quality class, where the degree of eutrophication is mesotrophic due to water load with organic waste. In the next two years the amount of phosphorus decreases, thus determining the lake to become oligotrophic. In the second period the amounts are much smaller, but oscillatory. So the years 2011 and 2015 even reach the best degree of eutrophication - ultra-oligotrophic. This improvement of the water body can be put down to the effectiveness of controls at tourism facilities on the lake. 


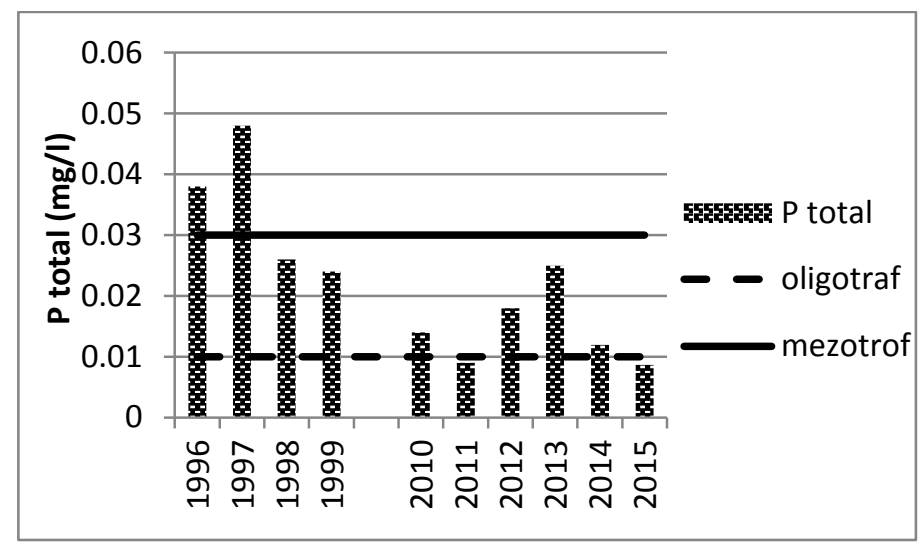

Fig. 8. Total phosphorus variation

The evolution nutrient parameters show the diversified influence of natural conditions in the catchment area and the contribution of the human factor to the change in water body quality.

\subsection{Standard deviation}

In the analyzed period (2010-2015) the $\mathrm{pH}$ has a greater standard deviation at the beginning and end of the analyzed period. The values from 2012-2014 show a relative uniformity (0.08-0.12). Maxima (0.27) from 2010 expresses a great dispersion of individual values around the average.

The oxygen regime, also through its standard deviation, shows a fluctuating trend. Data variability is greater for dissolved oxygen than for the biochemical oxygen demand. Oxygen values have a large dispersion in 2010 and 2013-2015. Instead in 2011 and 2012 there are significantly lower values (0.07, 0.03 respectively). For biochemical oxygen there is only one high value in 2012 (1.02). In other years the values are below 0.5 .
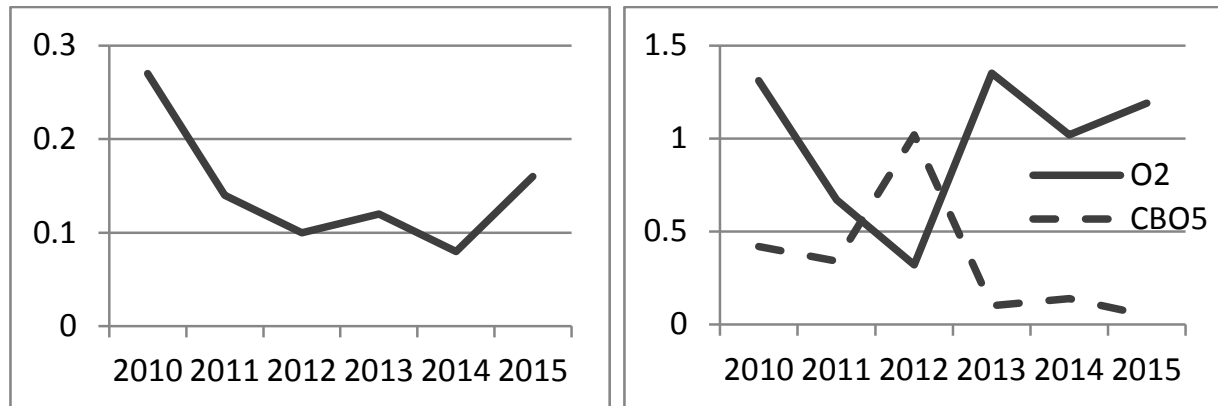

Fig. 9. pH and oxygen regime's standard deviation

In the nutrient group, the total nitrogen values are high and register the largest amplitude (0.2) for standard deviation. Ammonium shows a slight maximum in the last year of study, with relatively small amplitude variation. Deviations of total phosphorus and phosphate are homogeneous at very low values. 


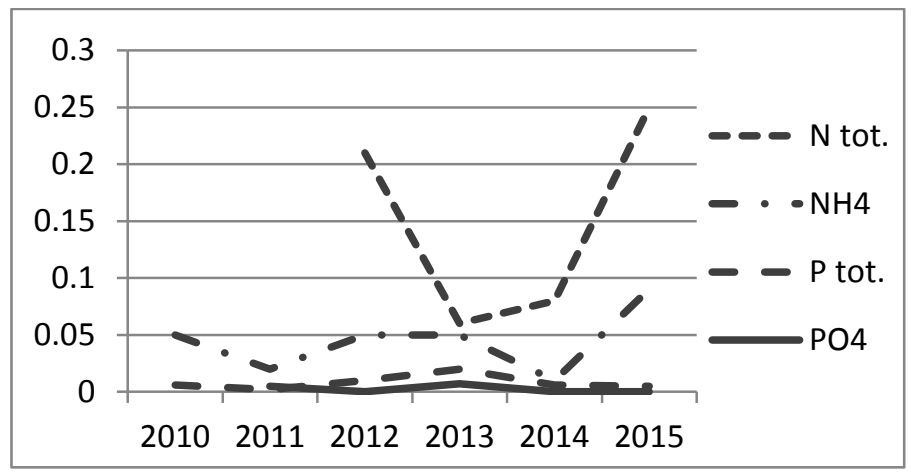

Fig. 10. Nutrients' standard deviation

\section{CONCLUSIONS}

The water quality for this ecosystem is in accordance with the specific condition of the reference lake type - natural lake. After evaluating the indicators, it can be observed that the water from Red Lake belong to the category of mountain waters, relatively clean, indicating a moderate ecological status for nutrients, and a good quality for the other indicators, according to the Order 161/2006.

The acidification conditions, respectively the $\mathrm{pH}$, indicate a low alkaline water. The oxygen regime includes the water from this lake into the $\mathrm{II}^{\text {nd }}$ global quality class, due to the high levels of dissolved oxygen from the year 1999. From the nutrients, the highest problems are triggered by the high ammonium values from the year 1999, which include Red Lake in the II $^{\text {nd }}$ quality class. The lake is included in the III ${ }^{\text {rd }}$ eutrophication class for total phosphorus, respectively mezotroph, for the years 1996 and 1997. After these years, the lake's situation is getting better.

The standard deviation presents the highest dispersion value for dissolved oxygen (1.12), and the minimum values appears for phosphate (0.007).

In the future, due to the fact that Red Lake and the region surrounding it is an important touristic objective, this activity should be done with more exactness.

\section{REFERENCES}

1. Pandi G. (2004), A Gyilkos-tó, hidrogeográfiai tanulmány, Edit. Casa Cărții de Știitnță, Cluj

2. Romanescu Gh., Stoleriu C.C., Enea A. (2013), Limnology of the Red Lake, Romania, Ed. Springer, London

3. Vigh M. (2003), A Gyilkos-tó vízminősége a klasszikus szennyező elemek függvényében, EME, Cluj

4. *** (2006), Normativ privind clasificarea calităţii apelor de suprafaţă în vederea stabilirii stării ecologice a corpurilor de apă, MMGA, OM 161/2006, Monitorul Oficial Partea I nr. 511 din 13 iunie 2006

5. http://statisticasociala.tripod.com/parametri.htm

6. https://statistics.laerd.com/statistical-guids/measures-of-spread-standarddaviation.php 